AGATA AUSTEN

MICHAŁ KAPIAS

\title{
Decoupling between policy and practice through the lens of sensemaking and sensegiving'
}

Prof. Agata Austen University of Economics in Katowice

Michał Kapias, PhD University of Economics in Katowice

\section{Introduction}

The essence of operating rules in the organizations is the introduction of a set order which becomes the basis for the actions of its members. In other words, members of the organization change their environment (reality), adapting it to their needs. As the organizations are not lonely islands, they are forced to take into account other organizations or groups called stakeholders. Sometimes, however, a difference of opinion, lack of understanding, or a discrepancy in expected goals take place which may bring tension and conflict. In such situations there is a need for rules that will govern appearing disharmony. Unfortunately, the very emergence of the rules does not guarantee the existence of the necessary changes for conflict resolution. To function effectively, rules should be established, announced and understood in a proper way. Unfortunately, there are situations in which organizations read the

1 The paper was prepared as part of the project: "Information management and communication in public organizations", University of Economics in Katowice, 2014-2016. 
expectations of stakeholders inappropriately, or the above conditions have been met, but the rules still do not work. Changes are not made, because for some reasons member of the organizations ignored them, or even deliberately removed from the perspective of organizational life. The question is: what are the reasons for this situation which we can call decoupling?

Interest in decoupling in organizations has begun already in the 70s of the last century. It was noticed that in various organizations quite amazing situations take place. Efforts aimed at creating a strategy or standards of conduct, which are essentially designed to improve any area of the organization, are taken, but they remain ultimately only a "dead letter", or "idée fixe" which are finally not implemented. You can say that these rules were established symbolically and essentially never would have practical application - even though sometimes the idea was born from a deep desire to modernize the existing organizational solutions. There is thus a kind of separation between what is declared and what is implemented.

Although the term "decoupling" often refers narrowly to a gap between policy and practice, this is not its only manifestation. Citing J.W. Meyer and B. Rowan (1977, p. 343): "Structural elements are only loosely linked to each other and to activities, rules are often violated, decisions are often unimplemented, or if implemented have uncertain consequences, technologies are of problematic efficiency, and evaluation and inspection systems are subverted or rendered so vague as to provide little coordination."

There are different reasons for the gap between policies and practices. This can be both complexity of tasks and intentional actions aimed at encryption of the actions taken by organizations (Scott, 2008). P. Bromley and W.W. Powell (2012, p.517) present different hypotheses about presence of decoupling: “(a) more emphasis is placed on implementing policies, (b) policies are selected in part because they can be implemented and measured, and (c) pressures in the environment that drive the creation of policies may independently be changing practices and outcomes, regardless of policy implementation".

This article presents two processes which, although they appear separately, are closely related to each other: sense making: and sense giving. The aim of this article is to suggest the potential importance of these processes for the phenomenon of decoupling, as well as to present the role of ethical awareness for eliminating decoupling that results from conscious actions of organizational actors. 


\section{Decoupling: theoretical background}

The development of management sciences as well as emphasis on transparency of actions are changes in the organization surroundings, the consequence of which is growing stress on adjustment of organization policies and practices to satisfy the stakeholders' expectations. Changing regulations and requirements in the scope of audit, consumers' safety or provisions regarding environment protection and employees' rights as well as occurrence of rankings, standards of non-obligatory nature, lead to formation of contradictory aims (Bromley, Powell 2012). Surviving of organizations often depends more on adjustment to normative expectations than on increasing of its economy of their actions. It also refers to commercial organizations (e.g. requirements in the scope of business social responsibility) and public organizations (e.g. situations of decision politicization). The stakeholders' pressure usually leads to adjustment of policies, but practical actions do not always follow them. The smaller the cohesion between the stakeholders' expectations towards the organization (consensus between the stakeholders) and their knowledge about organization (information asymmetry), the larger the probability of occurrence of splitting.

Decoupling has its roots in neo-institutional theory whichaffords insight into why organizations adopt policies that they are unable or unwilling to implement, positing that policy-practice decoupling helps organizations to buffer internal operations from external pressures. Meyer and Rowan (1997) assume that the institutional attitude described organizations in the categories of social convictions. They perceive splitting as a consequence of organization isomorphism under the assumption of slight reality understanding. In accordance with this view certain formal aspects of reality arise not as a result of needs connected with the production, but as an effect of rationalizing the pressure of environment, which is connected with assuring legitimization and intention to avoid sanctions or being pilloried by the public opinion. This early conceptualization attributed the discrepancy between the policy and practice to loose connection between the problems and choices.

In accordance with the neoinstitutional theory, an organization tries to obtain legitimization by creating visible, mostly symbolic policies which make a pretence that the expectations or requirements with regard to the organization are met (MacLean, Behnam 2010). Decoupling is a phenomenon that allows organizations to satisfy the external stakeholders without disturbing current internal activities. In accordance with this approach, many formal rules are "myths and ceremonies". 
One of new approaches to institutional analysis is institutional logics. It focuses on how competing societal-level belief systems shape both individuals and organizations. Thornton and Ocasio (2008, p. 101) developed a widely used definition of institutional logics as "the socially constructed, historical patterns of material practices, assumptions, values, beliefs, and rules by which individuals produce and reproduce their material subsistence, organize time and space, and provide meaning to their social reality." They suggest that: "By providing a link between institutions and action, the institutional logics approach provides a bridge between macro, structural perspectives and more micro, process approaches" (Thornton, Ocasio 2008, p. 99)

Most considerations regarding decoupling are carried out at the macro level. However organizations may reply to the pressure of the environment in different ways. This is why in order to understand the phenomenon of splitting, it is important to take into account variables at the level of organization. D. Crilly and the team (2012) propose to distinguish two factors at the level of organization: managerial consensus and interest perceived in implementation of policy. Firstly, organizations do not have to reflect differentiation of the environment, because legitimization is created also internally. The pressure to submit to conflicting interests may be weakened by top management through giving priorities to particular groups of stakeholders - assuming the expectations of one of the groups as the most important we can diminish the managers' uncertainty whose interests are to be taken into account. The managerial staff may strengthen this understanding by creating formal instructions and a system of sanctions. Another way is also to reduce decision autonomy of subordinate employees in the scope of disposing of resources. Even in spite of lack of formal control strong leadership and actions directed at using shared values may diminish the probability of the occurrence of decoupling. The second issue is the interest that the given organization has in the performance of the given direction of actions and relationships with the given group of stakeholders. The reaction of an organization does not always have to be splitting. Organizations sometimes aim at reduction of information asymmetry by revealing information on organization functioning or by allowing the stakeholders to observe functioning if maintaining such relationships with the stakeholders is profitable for them.

M. Sauder and W.N. Espeland (2009, p. 63) claim that "decoupling is not determined solely by the external enforcement of institutional pressures or the capacity of organizational actors to buffer or hide some activities. Members' tendency to internalize these pressures, to become self-disciplining, is also 
salient." Hence, we also base our considerations on behavioral theory which gives the basis for understanding of these issues.

\section{Sensemaking and sensegiving in the context of decoupling}

Actions and interests of individuals are perceived as a central determinant of decoupling between policies and practices. the institutional theory and identity perspectives focus on macro-determinants of organizational attention, internal determinants of organizational attention have been examined from Behavioral Theory of the Firm. Micro-processes play a large role in determining whether a practice becomes a routine part of organizational life or remains largely as an empty promise. Focus on the individual level, including mechanisms used by members to interpret institutional forces, can help to understand what are the "guts" of organizations in accordance with the neoistitutional theory (Sinthcombe 1997).

M.B. Gondo and J.M. Amis (2013) propose that the phenomenon of decoupling is the result of different levels of acceptance and implementation. First, a newly introduced idea does not appear in the organization fully formed with a clear definition or use. The members of the organization need to articulate an appropriate meaning and work out reasonable uses for the imported practice or model. In order for a practice to become accepted, it must first make sense. Sensemaking is a process by which people give meaning to the experience. Sense is made as individuals undertake an active justification process using both internal and external sources to persuade participants of the value of adopting the practice (Gondo, Amis 2013). As K.E. Weick $(1993,635)$ suggests, "the basic idea of sensemaking is that reality is an ongoing accomplishment that emerges from efforts to create order and make retrospective sense of what occurs". Sense-making is inherently retrospective and precedes action because situations are only understood upon completion. Thus, it is a key micro mechanism of institutionalization that allows consideration of both the "cognitive complexities" that guide organizational behavior and recognition of the varied ways that institutionalized practices operate at the micro-level (Jennings, Greenwood 2003).

If sensemaking process is successful, the abstract practice that has been diffused across may be accepted by participants in an adopting organization and finally implemented. The implementation dimension relates to whether those adopting a practice do so in a more or less conscious manner. In order for a practice to be implemented, managers must build into the practice 
certain interpretive schemes, facilities and norms that describe resources to accomplish work and a way of executing work. If the level of acceptance and conscious actions is high, there will be a real change at the organizational level. If both dimensions are at a low level - the intended decoupling will be a result (a formal implementation without any real change in the activities of members of the organization). Alternatively, unintended decoupling occurs (lack of full integration of new practices in the operation of the organization), if the level of acceptance of the practices is high, but their implementation is not accompanied by conscious reflection. On the other hand, in the latter situation (a low level of acceptance, the high level reflection), change in the practices take place (Gondo, Amis 2013).

Commonly using the concept of "meaning" is pointing to any right occurring phenomenon or taken action. It may be noted, that the notion of sense reveals a certain purposefulness as well as rationality. In this context, a deeper analysis of sense would lead to the indication of such factors or elements in actions, which- while negated - would lead to the negation of the same phenomenon (Krapiec 1998, p. 301). These are the constitutive elements that construct the given reality to show its right (Maryniarczyk 2004, p. 70). In other words, meaningful are those activities that are aimed at a planned goals, and these activities that may be comprehended and judged by people. In this case, you can also point to the logic of what makes sense. In addition, sense is strictly associated with the category of truth. The truth "does not have degrees", and is an "objective property "(Frege 2001, p. 38). For example, considering the category of "beauty" we may notice, that something is beautiful for someone, but not for another person. Otherwise, however, it looks in the case of a sentence - it cannot be "a little" real. As a consequence, truth becomes a kind of correctness showing a logical meaning of the expression (Kapias, Polok 2014, p. 39). Managers usually are aware of the facts that occurred, but under pressure from different stakeholders, or in the face of self-interest, they may distort, trim, or radically misinterpret the reality. This creates "new facts", the "new world". Therefore, there is no unambiguous transmission of information in the actions of managers, because these are filled with vagueness and conceptual inaccuracy which is often manifested in a purposeful chaos of data. Permanent or universal principles governing the cognitive - communication process are contested. This ensures that every interpretation turns out to be fair and reasonable, as interpretation using the opposing arguments. And the voices calling for the adoption of uniform criteria and rules shall be regarded as a manifestation of intolerance or ideological totalitarianism. The meaning of reality that surrounds human beings in no 
longer read, but sense is being created for individualized purposes. If sense is produced by an individual it is more likely that the decoupling will take place, and if meaning is being read from reality (is somehow independent of the individual) then it is easier to make a rational decision and agree on guidelines, principles, rules, etc. Taking into considerations the discussion above, we formulate the following hypothesis:

Hypothesis H1: Sensemaking based on particular interests of individuals will lead to decoupling etween policies and practices.

We propose to fill in the understanding of acceptance dimension with sensegiving which is concerned with the process of attempting to influence the sensemaking and meaning construction of others toward a preferred definition of organizational reality (Gioia, Chittipeddi 1991, p. 442). It is an interpretative process in which actors influence others through persuasive language. Sensegiving is an activity both of leaders and of other organizational stakeholders.

Usual sensegiving proceeds between managers at various levels as well as between managers and employees. Usually, leaders shape the interpretations of others through the formulation of the identity declaration. As a result of the sensemaking and sensegiving efforts, the original abstract vision becomes redefined. Top management teams may make some adjustments and then steer actions towards realization of the practices (Gioia, Chittipeddi 1991). Thus we claim that:

Hypothesis 2: Both sensemaking and sensegiving shape level of acceptance and thus possibility of decoupling between policies and practices.

Maitlis and Lawrence (2007) propose that (1) "leaders will be motivated to engage in sensegiving when they perceive issues as ambiguous and unpredictable and/or as involving numerous, diverse stakeholders (p. 77), and (2) leaders will be more able to engage in high levels of sensegiving in issue domains in which they possess relevant expertise and/or in which their organizations are already performing effectively" (p. 79). Sensegiving may serve as a social strategy to guard against change. Sensegiving, when evolving from conflicting viewpoints, accounts, and actions can support lack of consistency. It may serve the interests of a management that pursues different path than declared politics bolstered by internal interests, even if at the expense of better results (Drori, Ellis 2011). 
Therefore we posit that:

Hypothesis H3: Sensegiving based on particular interests of individuals will lead to decoupling between policies and practices.

\section{Decoupling and responsibility issues}

Recent studies call for making a distinction between decoupling due to a lack of capacity versus decoupling due to lack of will (Cole 2012). Some actions taken by organizational members may even take a form of "acts of omission or commission committed by individuals or groups of individuals acting in their organizational roles who violate internal rules, laws, or administrative regulations on behalf of organizational goals" (Vaughan 1999, p. 288). Policypractice decoupling is more common when it serves the interests of powerful leaders (Bromley, Powell 2012). In other words, networks of top managers and organizations become skilled at symbolic manipulation. Using the pressure/ opportunity theoretical explanation, one may assess organizational actors as amoral rational calculators: when faced with limited access to or scarcity of resources, they weigh the benefits of misconduct against the costs of such rule breaking. If the benefits outweigh the costs, they choose misconduct without checking a moral compass (Finney, Lesieur 1982). In this context ethical aspects of human behavior seem to be significant.

The phenomenon of decoupling each time occurs in the area of human activity. Therefore one can assume that the subject is a human being. Since the human's behaviour is indicated, it can be considered in the aspect of morality, which "itself is life and an area of life, is connected with human activity" (Wojtyła 1995, p. 13). In other words "morality can be defined as human's actual behaviour his actions, attitudes, opinions, and everything in the context (in relation to) the good of a human" (Gałkowski 2002, p. 16). In the same way a human as a rational and volitional being can consciously create his identity as well as the world that surrounds him in the perspective of performed moral good or wrong. In its actions, a human being develops its own personality as well as have an impact on the reality which exists. It can be transformed, improved or destroyed, and these actions will bring measurable effects.The changes influence also (more than once in an extremely painful way) the author himself. In this context there occurs the category of responsibility, which through human behaviour shapes identity as well as impacts the reality, in which a human exists. One can transform, improve or damage it. However the tendencies bring rational 
results. Changes are distinctively characterized by human being (Kapias 2011, pp. 19-38). It bears in a way two dimensions. The first one occurs in a typically juridical context, the second one - in an ethical context. The legal aspect is connected with the codification of Roman law and occurs in terms: respondere, responsum and responsio. They regard the responsibility for something or before somebody (Picht 1981, p. 232; Kamiński 1986, p. 134). The second dimension of the discussed issue occurs in the prism of the term imputation (assignment, assumption). It is suggested that the responsibility in this context means an act, the author of which is fully conscious and free object of action. Therefore he is able to control his act and be aware of what he does (Podsiad, Więckowski 1983, col. 273). A reasonable action causes that it belongs to its author. This result connection causes that there is a responsibility for this act (Ślipko 1974, pp. 348 - 349). The responsibility occurs as a condition of human's self-realization thanks to which he is open to other people and their values. It is a kind of ability to overcome oneself, one's own weaknesses or addictions and at the same time the ability to assess oneself and verify one's own doings (Tchorzewski de 1998). The most important condition of responsibility is that fact that a human impacts the world and its transformations. It is worth noticing that such action is subject to auto-control. Thanks to this a human can to some extend foresee (that is imagine) the results of his action (Kofta 1989). "If these conditions are met, there is a possibility of responsibility, but in two very different senses: (1) responsibility as being accounted $>$ for $<$ one's actions, whatever they were, and (2) responsibility $>$ for $<$ the given subjects, which engage the author to particular acts with regard to the subjects" (Jonas 1996, p. 167). In the first case the author is acknowledged as responsible for the results of his actions. It has mainly legal dimension as potential punishment for damage or prize for the good must be justly compensated no matter if the author attributed to such state of affairs personally or only indirectly (e.g. as a manager of working employees). Only after juristic compensation there occurs the moral dimension of incurred responsibility The second case refers not so much to the performed situation, but rather to a situation that will only take place. "This $>$ what for $<$ (I am responsible) lies beyond me, but in an effective range of my power - needing it or being endangered by it" (Jonas 1996, pp. 169-171). In other words being aware of the fact of existing in a specific world and time, a human is also aware that there are some challenges, tasks to be performed before him that result from the fact that he is this and not another person. (If he is e.g. a director, then he is responsible for his subordinates and if he is a businessmen then - for the business - even the one that he has not performed yet, but should due to his status). 
These digressions appear very important in the context of decoupling. It must be assumed that in complex interpersonal relationships that occur in the complex process of management, one of the key categories is responsibility. If used by human beings, responsibility makes it possible to fully develop humanity, and thus actually affects the world surrounding people. Therefore there is a fundamental need for increasing awareness of all participants in the management process as its success, efficiency, and the expected effect depends largely on taking responsibility for taken actions. Implementation of responsible attitudes and actions also favors the elimination of the unfavourable effects of decoupling.

It turns out that the individual who feels responsible, may take series of relationships and activities occurring in the management process. On the one hand such individuals create politics and directives that are less utopian and more adapted to the specific situational conditions. On the other hand- those designed to implement them not reject ignore, nor disregard them, because strong sense of responsibility makes them obligatory and rational actions. In this way, the relationship between the top managers of a particular organization or team managers, and individuals becomes more valid and meaningful. Thus:

Hypothesis 4: The greater sense of responsibility both for own behavior of individuals, as well as for the actions of co-workers, the less the likelihood of decoupling.

Accepted and respected ethical principles will foster the attempts of better communication, understanding, and finally fulfilling the tasks resulting from mutual interpersonal relationships appearing in the organization. Hence, there is a need to increase ethical and axiological awareness of management processes. Therefore:

Hypothesis 5: Raising ethical awareness of managers and employees should contribute to decreasing the probability of decoupling.

Development of ethical attitudes of employees always contributes to the improvement of interpersonal relationships, as well as to the greater moral good of individuals. Hence, in the face of emerging problems arising from decoupling, increasing ethical awareness should translate into higher organizational effectiveness.

\section{Conclusions}

The phenomenon of decoupling has its own extensive reference in many modern scientific research. They can be found in economics, sociology or political 
science, but also physics or mathematics. There is no doubt that some practices are purposefully decoupled from day-to-day activities for legitimacy reasons or because organizations adopting a practice believe that it lacks consistency with existing intraorganizational dynamics. In some situations the reason may be the limitation of human nature.

For some personal or social reasons, managers make decisions conducive to the organization or selected groups of stakeholders, but their findings may be in conflict with earlier findings undertaken. This leads to the satisfaction of selected individuals, and also generates attitudes based on decoupling. So ultimately it must be assumed that if the bases for sensemaking and sensegiving are constituted of the particular, individualized interests (of managers, external stakeholders or employees), the ongoing are projects expected to result in decoupling. This is facilitated by a situation of lack of control, or ineffective controls over managers. It turns out, however, that the problem could be - at least partially - solved when ethical principles are enhanced and improved. Building a sense of responsibility in a team gives more sense to both decisions and their implementation. It also affects the proper understanding and realization of these guidelines. Perhaps putting emphasis on ethical issues cannot eliminate decoupling completely, but will foster its restriction.

In our paper we used theory of sensemaking and sensegiving to explain the phenomenon of decoupling. We hope that presented hypotheses will serve as inspiration for empirical research.

\section{Summary}

\section{Decoupling between policy and practice through the lens of sensemaking and sensegiving}

Any organizations, pursuing their goals, they should take into account others, as they are compelled to a joint coexistence. In order to grow, they need plans and rules of conduct. But not always what was intended is actually implemented. That discrepancy is called decoupling. This phenomenon may be due to different levels of acceptance and implementation of rules, which is associated with the process of sensemaking and sensegiving. The first phenomenon involves the creation of meaning, where the new rule is not yet fully developed and understood, and so it must be properly interpreted only to implement the action. In this process, people give meaning to their experiences. If the process of creating a sense is successful, occurring practices are accepted 
by the members of the organization, and finally implemented. Sensegiving is about exerting influence in terms of the proper understanding of the rules, in order to create an appropriate definition of organizational reality. Moral attitude of employees may be important in minimizing the effect of negative attitudes associated with decoupling. Therefore, there is a need for constant training of employees in ethical issues.

The aim of the article is to present the potential significance of sensemaking and sensegiving for decoupling, and explain the role of increasing ethical awareness for neutralizing decoupling resulting from conscious actions of organizational actors.

Keywords: decoupling, organizational behaviors, sensemaking, sensegiving.

\section{Streszczenie}

\section{Zjawisko rozdzielenia między polityką a praktyką działania $\mathrm{z}$ perspektywy nadawania i tworzenia sensu}

Jakiekolwiek organizacje, realizując swe cele, winne liczyć się z innymi, gdyż są skazane na wspólną koegzystencję. Aby mogły się rozwijać, potrzebują planów i reguł postępowania. Nie zawsze jednak to, co było zamierzone, jest faktycznie realizowane. Owa rozbieżność nosi nazwę rozdzielenia. To zjawisko może być wynikiem różnych poziomów akceptacji i implementacji zasad, co związane jest z procesem tworzenia i nadawania sensu. Pierwszy polega na tworzeniu sensu, gdzie nowa zasada nie jest jeszcze w pełni ukształtowana i zrozumiana, a więc trzeba ją dopiero odpowiednio zinterpretować aby wdrożyć w działanie. $W$ procesie tym ludzie nadają znaczenie zaistniałemu doświadczeniu. Jeśli proces tworzenia sensu jest pomyślny, zaistniałe praktyki są zaakceptowane przez członków organizacji, a w końcu wdrażane. Drugim procesem jest nadawanie sensu, gdzie wywiera się wpływ na pracowników w zakresie odpowiedniego rozumienia reguł, w celu wykreowania odpowiedniej definicji rzeczywistości organizacyjnej. Aby zminimalizować zjawisko negatywnych postaw związanych $\mathrm{z}$ rozdzieleniem istotną rolę odgrywa przyjmowana postawa moralna pracowników. Ważną kategorią staje się odpowiedzialność. Dlatego też zachodzi potrzeba stałego dokształcania etycznego pracowników organizacji. 
Celem artykułu jest przedstawienie potencjalnego znaczenia jaki mogą mieć wskazane procesy dla zjawiska rozdzielenia, a także przedstawienie roli zwiększania świadomości etycznej dla niwelowania zjawiska rozdzielenia, wynikającego ze świadomych działań aktorów organizacyjnych.

\section{Kluczowe}

słowa:

rozdzielenie, zachowania organizacyjne, tworzenie i nadawanie sensu dziatania.

\section{References}

1. Bromley P., Powell W.W. (2012), From smoke and mirrors to walking the talk: Decoupling in the contemporary world, "The Academy of Management Annals", No. 6.

2. Cole W.M. (2012), Human rights as myth and ceremony? Reevaluating the effectiveness of human rights treaties, 1981-2007, "American Journal of Sociology", Vol. 117 (4).

3. Crilly D., Zollo M., Hansen M. (2012), Faking it or muddling through? Understanding decoupling in response to stakeholder pressures, "Academy of Management Journal", No. 55.

4. Drori I.; Ellis S. (2011), Conflict and power games in a multinational corporation: sensegiving as a strategy of preservation, "European Management Review", Vol. 8, Issue 1.

5. Finney H.C., Lesieur H.R. (1982), A contingency theory of organizational crime, "Research in the Sociology of Organizations", No. 1.

6. Frege G. (2001), Schriften zur logik und sprachphilosophie, Felix Meiner Verelag, Hamburg.

7. Gałkowski J.W. (2002), Zasady etyki zawodowej - etyka biznesu, [in:] M. Borkowska, J.W. Gałkowski (eds.), Etyka w biznesie, TN KUL, Lublin.

8. Gioia D.A.; Chittipeddi K. (1991), Sensemaking and sensegiving in strategic change initiation, "Strategic Management Journal", No. 12 (6).

9. Gondo M.B., Amis J.M. (2013), Variations in practice adoption: the roles of conscious reflection and discourse, "Academy of Management Review", No. 38.

10. Jennings P.D., Greenwood, R. (2003), Constructing the Iron Cage: Institutional Theory and Enactment, [in:] R. Westwood, S. Clegg (eds.), Debating organization: pointcounterpoint in organization studies, Blackwell Publishing Ltd., London, UK.

11. Jonas H. (1996), Zasada odpowiedzialności. Etyka dla cywilizacji technologicznej, Wyd. Platan, Kraków.

12. Kamiński J. (1986), Respondere, [in:] W. Wołodkiewicz (ed.), Prawo rzymskie. Stownik Encyklopedyczny, PIW, Warszawa. 
13. Kapias M. (2011), Odpowiedzialność moralna fundamentemodpowiedzialności społecznej organizacji, [in:] G. Polok (ed.), Społeczna odpowiedzialność aspekty teoretyczne i praktyczne, „Studia Ekonomiczne. Zeszyty Naukowe Uniwersytetu Ekonomicznego w Katowicach", No. 64.

14. Kapias M., Polok G. (2014), Public relations - kreowanie czy odczytywanie sensu, [in:] A. Frączkiwiecz-Wronka, J. Gołuchowski, A. Adamus-Matuszyńska (ed.), Public relations. Doskonalenie procesu komunikowania w przestrzeni publicznej, „Studia Ekonomiczne. Zeszyty Naukowe Uniwersytetu Ekonomicznego w Katowicach", No. 185.

15. Kofta M. (1989), Orientacja podmiotowa: zarys modelu, [in:] Kofta M. (ed.), Wychowanek jako podmiot dziatan, Wydawnictwa Uniwersytetu Warszawskiego, Warszawa.

16. Krąpiec M.A. (1998), Metafizyka, TN KUL, Lublin.

17. MacLean T.M., Behnam M. (2010), The Dangers of Decoupling: The Relationship Between Compliance Programs, Legitimacy Perceptions, and Institutionalized Misconduct, "Academy of Management Journal", Vol. 53, No. 6.

18. Maitlis S., Lawrence T.B. (2007), Triggers and enablers of sensegiving in organizations, "Academy of Management Journal", Feb, Vol. 50, Issue 1.

19. Maryniarczyk A. (2004), Pluralistyczna interpretacja rzeczywistości, Polskie Towarzystwo Tomasza z Akwinu, Lublin.

20. Meyer J. W., Rowan B. (1977), Institutional organizations: Structure as myth and ceremony, "American Journal of Sociology", No. 83.

21. Picht G. (1981), Odwaga utopii, PIW, Warszawa.

22. Podsiad A., Więckowski Z. (1983), Poczytalność, [in:] Mały stownik terminów i pojęć filozoficznych, Wyd. Pax, Warszawa.

23. Sauder M., Espeland W.N. (2009), The discipline of rankings: Tight coupling and organizational change, "American Sociological Review", Vol. 74 (1).

24. Scott R.W. (2008), Institutions and Organizations. Third ed., Sage Publications, Inc, Thousands Oaks, CA.

25. Stinchcombe A.L. (1997), On the virtues of the old institutionalism, [in:] J. Hagan, K.S. Cook (eds.), Annual review of sociology, No. 23, Annual Reviews, Palo Alto, CA.

26. Ślipko T. (1974), Zarys etyki ogólnej, WAM, Kraków.

27. Tchorzewski A.M. de (ed.) (1998), Odpowiedzialność jako wartość i problem edukacyjny, wyd. WERS, Bydgoszcz.

28. Thornton P.H., Ocasio W. (2008), Institutional logics, [in:] R. Greenwood, C. Oliver, R. Suddaby, K. Sahlin (eds.), The Sage handbook of organizational institutionalism, Sage Publications, London, UK.

29. Vaughan D. (1999), The dark side of organizations: mistake, misconduct, and disaster, "Annual Review of Sociology", No. 25.

30. Weick K.E. (1993), The Collapse of Sensemaking in Organizations: The Mann Gulch Disaster, "Administrative Science Quarterly", No. 38.

31. Wojtyła K. (1995), Elementarz etyczny, Wyd. TUM, Wrocław. 